\title{
Miklós Szanyi \\ Varieties of development paths in post communist countries with special regard to the transition in Hungary
}

\begin{abstract}
Transition in Central and Eastern Europe was carried out in various ways. However, the different countries' current economic structure, institutions and main economic performance measures are rather similar. The question asked is whether these countries follow a specific kind of development model? What seems likely is that they differ substantially from CIS countries in many aspects. But they also seem to differ from existing models of capitalism more than they do from each-other. Based on this information, the varieties of capitalism literature assumes that such a model does indeed exist. However, no comprehensive positive description of the model has so far been provided. This paper tries to define the main elements of the CEE capitalist models. These are small open economies, with close integration into the world economy through foreign investments, a relatively limited and declining role of state redistribution, the problems of dual economic structure and insufficient job creation, a relatively large shadow economy and "business capture"-type cronyism. Further research is required to properly describe the elements and interactions among them.
\end{abstract}

Journal of Economic Literature (JEL) classifications: D72, E65, P31

Keywords: varieties of capitalism, transition, Central and Eastern Europe, privatization, FDI

Central- and Eastern European countries underwent two major systemic changes in the 20th century. Both of them were directed by some kind of uniform ideological background. In the case of Central Europe the socialist transition was engineered to fit Soviet models and political expectations. This doctrinaire policy lasted for a long period in some countries (Czechoslovakia, Bulgaria or the GDR), while Yugoslavia, Hungary and Poland experimented with variations to the model in order to overcome some of the most severe bottlenecks of the socialist economic system (e.g. lack of price orientation, low level of working morale and incentives). Nevertheless, strong state paternalism, soft budget constraints, isolation from world markets and international competition remained in place. Still, the communist experience of Central-European countries was not totally uniform.

Szanyi Miklós a Debreceni Egyetem Közgazdaság-és Gazdaságtudományi Karán egyetemi tanár, a DE Közgazdaságtudományi Doktori lskola vezetője, az MTA KRTK Világgazdasági Intézet tudományos tanácsadója. E-mail:miklos.szanyi@econ.unideb.hu

The work/publication is supported by the TÁMOP-4.2.2/B-10/1-2010-0024project. The project is co-financed by the European Union and the European Social Fund. 
The second systemic change was back to a market economy. At the very beginning of the process the Washington Consensus was still in place and international organizations and advisers recommended the neoliberal transition treatment expressed in the acronym SLIP (stabilization, liberalization, institution building and privatization). Although advisers' opinions changed rather slowly, the various transition economies applied SLIP with wide variations in sequencing and timing. Some elements were postponed or never implemented. In the case of institution building a large variety of models was used. Hence, transition economies have developed in largely different ways during the past 25 years. Uniformity has remained in place only in terms of international organizations and financial institutions. These have continued to evaluate transition and economic performance using sometimes rather arbitrary, uniform schemes of measurement.

Thus, after almost 25 years the transition process has created quite differing new market economic systems in Central and Eastern Europe. At the same time, new branches of economic thought have become established that compared the transition process and the variety of capitalist systems in order to find best practices. The varieties of capitalism (VoC) literature aimed not only at providing advice for transition economies, but also reforming mature market economies' ailing systems (e.g. social security and innovation systems). This new branch became part of a larger stream of economic thought: comparative economics.

The use of $\mathrm{VoC}$ literature on transition economies has been rather ambivalent. While it tried to identify good solutions for institutional structure and policies using the experiences of established market economies, it did not succeed in finding general best practices, and suggested solutions were rarely implemented. On the other hand, diverse transition trajectories fuelled important discussions on the same topic. Varieties of transition were described and analyzed with the same aim: finding best practices for the different tasks of the transition process. Nevertheless, scholars of the VoC literature continue to compare Central and East European countries' capitalist models with established market economies (see: Farkas, 2011a). The main aim of this paper is to review the transition process in Central and Eastern Europe using results of comparative economics (especially VoC), and highlight the main features of the market economic systems of the region, but especially those of Hungary.

\section{Evidence from the VoC literature}

One of the most important questions of the comparative analysis of Central and East European market economies is whether there is a common model of transition and capitalism. To put the question another way, are cross-country differences within the region greater than the differences with other established market economies? Nobody would of course claim that the transition trajectories and current market economic models of the region are identical. But the argument of the German school which states that each case is different is not applicable either. There is no clear answer to this question; researchers' opinions are divided. In fact, few comprehensive analyses have been carried out with the aim of fitting transition economies into the more or less codified modeling structure of VoC 
literature using 4 or 5 types of capitalist models ${ }^{1}$ (Hall - Soskice, 2001; Amable 2003). Most researchers compare only countries within the region and figure out similarities and differences verbally with the 5 codified models, or try to establish new typologies within the region (Bohle - Greskovits, 2007; Csaba 2007). Little comprehensive research has been carried out using the same analytical tools for both established market economies and transition countries (Farkas 2011a).

What seems clear is that most CIS countries and transition economies of Central Europe follow very different development paths. Large CIS countries rich in natural resources run rather undiversified resource-based economies that are strongly controlled by the state and have weak democratic institutions but a rather autocratic political system (Lane 2007; Csaba 2007). Central European transition economies on the other hand have more developed and diversified economies that are integrated into the world economy through the presence of transnational corporations, and stronger democratic institutions which, however, do not work very effectively. This difference among the two groups is also reflected in the countries' external orientation - their relationship with the European Union ${ }^{2}$. But among CIS countries as well as among the new member states of the EU (the EU-10) important differences are also visible. The main question is whether these are as significant as the differences among the main capitalist models, and thus, can we create a new typology for the EU-10 (and CIS)? If not, then can the EU-10 be subordinated to the various types of capitalism known from the VoC literature, or do they together form a new capitalist model?

A comprehensive overview of the literature summarizes much of the EU-10-related VoC research results (Farkas 2011b). Many contributions attempted to relate transition economy features to the existing 5 capitalism models. The results were rather mixed. Berrou and Carrincazeaux (2005) ran a cluster analysis and found the Czech Republic, Poland and Hungary to be the Mediterranean model. Cernat (2006) found - quite surprisingly - that Bulgaria, Poland, Latvia, Lithuania, Romania and Slovakia were continental and the Czech Republic, Hungary and Slovenia rather Asian.

An important segment of the literature strongly emphasizes the relationships between the economic system and political stability, and differentiates between liberal and non-liberal (patrimonial) models of capitalism in the transition economies. King (2007) compares two models: the Czech Republic, Poland and Hungary (as liberal and dependent countries) with Russia, Ukraine, Romania and Serbia (patrimonial states). The former group differs from the West and is regarded as dependent because of the high importance of foreign investments and markets and the low level of coordination in the labor market. Bohle and Greskovits (2007) analyzed the relationships of economic change and new institutions and the related social costs of the change with political risks and behavior. They argued that the Baltic States ran a neoliberal model, mainly because these countries concentrated policies

\footnotetext{
1 While differences in capitalist development were registered and analyzed at least 150 years ago by Friedrich List and Karl Marx, or more recently by Max Weber, the VoC literature originates from the much referred studies of Peter Hall, David Soskice and Bruno Amable. They established a typology based on quantitative and qualitative information for established, traditional market economies differentiating among Anglo-Saxon, Nordic, Continental, Mediterranean and Asian models. The structure and functioning of capital-and labor markets, the social security system, and the extent and efficiency of state institutions were the most important areas where main differences among the models were described. 2 This is by and large a valid statement, although Csaba (2007) is of course right when he says that relationship to the EU per se does not determine a country's market economic system (see, for example, Greece). On the other hand, new EU members had to change their institutions according to the acquis, hence the process of accession had a strong influence on the transition process.
} 
on macroeconomic stability (a sign of vitality after breaking the ties with the Soviet empire and Russia). Although these policies had had extremely high social costs (in the form of GDP decline and high unemployment, as well as a rather unhealthy degradation of the economic structure), political stability was not challenged since the majority of the losers of the systemic change were industrial workers from the Russian minority. Many of them did not have citizenship and were excluded from the political arena. On the other hand, the Visegrad countries of Central Europe (the embedded neoliberal type) had undergone more gradual reforms and made strong efforts to compensate the losers of the transition process in order to accommodate the political consequences. An interesting conclusion was that this compensation was not based on a strong tripartite institutional system but on the arbitrary decisions of ruling governments. Bohle and Greskovits (2007) also differentiated a third type, the "neocorporatist", characteristic of Slovenia, which they regarded as the most successful, both economically and politically. Blanke and Hofmann (2008) also make a distinction between the Baltic States as a liberal model and various Central-European countries as coordinated market economies.

Some of the authors regard the EU-10 capitalist models as eclectic. The main reason for this is the arbitrary mix of the development of the various market economic institutions, stemming from various types of established capitalist economies. Cernat (2006) calls this "cocktail capitalism". The main problem of this system is that the components do not fit together if they come from economies working with differing logics. The clash of contradicting elements creates much space for opportunistic behavior for economic and political agents that may substantially deteriorate economic performance. The lack of institutional consistency creates situations where ad hoc decisions set the rules of game and thus state institutions and political parties gain great influence over the economy. This process is termed - based on the Russian experience - "business capture" (Yakovlev 2006).

Yet another approach regards the level of formal state intervention as the decisive factor in separating systemic models. This is not the same as the above mentioned arbitrary intervention of business capture, but reflects the aspects of either strong welfare institutions (the extension of central redistribution) and/or aspects of development state (Csaba 2007). When compared in terms of the extent of central redistribution the Czech Republic, Hungary and Poland have high levels similar to the traditional continental and Nordic models. On the other hand, Slovenia and Slovakia, and the Baltic states have significantly lower levels of state redistribution, which is similar to the Anglo-Saxon model of capitalism. Lane (2007) also uses the level of state intervention as the lead characteristic in his typology, albeit his country groups do not overlap with those of other authors.

Summing up, there is no clear research result concerning the analysis of the EU-10 countries' fit into the existing 5 traditional capitalism models of the VoC literature. Rather, results are contradictory, and vary according to the chosen selection criteria and also the observation periods. The EU-10 related VoC literature is nevertheless very valuable reading, since it provides much basic information on aspects of transition and new institutions, which helps readers to a better understanding of the non-orthodox processes that characterize most of these economies. In line with the lack of convincing evidence for the fit with existing models some authors tend to regard the EU-10 (sometimes even together with CIS countries) as a further new model of capitalism (EC 2008). Rodrigues (2009) also recommends the development of a new capitalism model for the transition economies and suggests some criteria. 
Farkas (2011a) carried out cluster analysis comparing the EU-25 on five institutional areas using measurable hard data. Her results have also been rather mixed in the various areas, but suggested that the EU-10 constituted a separate group in most respects. The calculations showed some degree of homogeneity within this group. Still, these calculations also suffered the usual handicaps of international systemic comparisons. The 5 areas investigated failed to capture many important aspects, and the chosen variables may be replaced by others that would perhaps show different results (the selection of indicators can always be criticized). Nevertheless, Farkas' contribution is currently the most comprehensive and methodologically most stable approach to the topic, with clear defendable results. Farkas (2011a) found similarities in the various areas of her observation with basically all European capitalist models. It seems, that the EU-10 implemented market economic institutions in mixed ways and can perhaps be really called cocktail capitalism. However, we do not share the opinion that this finding convincingly proves the existence of a separate model. We believe that it is a still open question as to whether the ongoing transition process will head towards one or another established market economic model, or will constitute a separate one. It is also possible that elements of the Russian-type capitalist model will gain importance, a point which has not been discussed by Farkas (2011a). Crony capitalism with increasing business capture by the state has been observed in some countries (e.g. in Hungary or Romania). Might crony capitalism possibly become the capitalist model of Central and east European Countries?

\section{The process of transition: main tasks and policy relevance}

The transformation in Central and Eastern Europe (CEE) included all major areas of social life. Changes in the main areas such as polity, society and economy interacted in many ways. Hence, the process can be best understood if treated in its complexity. For example, economic stabilization through austerity measures strongly reduced incomes and living standards, causing important changes in the political support for governments. On the other hand, the same measures established the basis for future prosperity in many countries, the benefits of which emerged with a substantial time lag, often under a new government. Therefore, political calculations, especially in the case of strong societal impacts, always influenced economic policy decisions, shaping the timing, extent and other aspects of important decisions.

Another important general determinant of transition was the widespread application of international consulting. International organizations and foreign governments often offered their advice services to CEE governments. Since transition from a planned economy to a market economy had never been experienced before, neither governments nor advisors had a solid empirical background to rely on. Hence, it was more likely that they would study and try to apply knowledge earned in somewhat similar cases using the prescription of the Washington Consensus' SLIP3. Due mainly to diverging political situations, actual policy steps differed widely among transition economies, albeit, the main

\footnotetext{
${ }^{3}$ The SLIP acronym stands for the initial letters of stabilization, liberalization, institutions and privatization, the main areas of neoliberal reforms, which were also very much relevant tasks of the transition process.
} 
logic of the policies remained the same and was reinforced by the consulting (and lending) international institutions.

The SLIP logic is very straightforward and is based on neoliberal assumptions about the strength of free market competition. Market economic institutions must serve the logic of free market competition, which will in the long run create favorable conditions for economic growth and prosperity. Two important conditions must enjoy preference in this process: the state must withdraw from direct activities in the economy (not only as owner, but also as planner), and macroeconomic stability must be provided in order to eliminate disturbing imbalances in market economic processes. In this regard strict fiscal policy and inflation centered monetary policy was suggested. Though the orthodox usage of SLIP was not typical for CEE transition, the main logic of a balanced budget and the priority of antiinflation policy still remains in place today.

The pace and sequencing of institutional changes, macro stabilization policies, liberalization and privatization varied greatly among transition economies ${ }^{4}$. This was mainly due to two factors. One was the difference in macroeconomic stability status (the level of foreign debt); the other was the main political concept of how economic transition should serve the political and societal changes in the CEE. Substantial levels of government and foreign debt forced Poland to undertake very drastic stabilization measures. Cutting the state budget expenditure as well as a deep devaluation of the currency shrank incomes drastically, causing a deep cut in welfare. Poland decided not to pay back the accumulated debt and initiated negotiations with commercial and government creditors. In contrast, Hungary wished to repay and tried to generate the necessary foreign currency income by selling state-owned enterprises to foreign investors in the privatization process.

In the case of Czechoslovakia ${ }^{5}$ the prevailing concept of economic transition was directly linked to political considerations. Governments tried to overcome a deep economic decline (called a "transformational recession" by Kornai (1994) through continued government subsidization of ailing industries, which was in fact contrary to the neoliberal concept of SLIP. Also, privatization policy was intended to serve political goals. A large proportion of state property was evenly distributed in the voucher privatization process among the Czech and Slovak nations. The aim of this was completely political: designers of this policy wanted to strengthen domestic capital ownership and create a new bourgeoisie that they hoped would support the government. This policy was only possible because the government was not indebted and hoped that the economy would recover soon through the use of state subsidies ${ }^{6}$. These examples could perhaps properly illustrate the strong impact of polity on economic transition. This interplay is conceptualized in Bohle and Greskovits (2007).

Growing imbalances in the early phase of transition need proper explanations of the reasons. Why was there a transformational recession with output drops of 30-40 \% (in some cases even more)? Kornai (1994) analyzed the main reasons for the recession. These were 1. the shift from a sellers' to a buyers' market, 2. the transformation of the real structure of the economy, 3. the disturbances in the coordination mechanisms, 4. the macroeconomic

\footnotetext{
${ }^{4}$ Roland (2000) provides an excellent overview of literature on the various aspects of SLIP in transition economies. Similar but less comprehensive summaries around the "10th anniversary" of transition were provided by Kornai (2000), Stiglitz (1999), Fischer (2000), EBRD (1999) and others.

5 This country ceased to exist in 1992, and the new Czech and Slovak Republics were established instead.

${ }^{6}$ This is another chapter in the saga of why this intention was not realized and the Czech and Slovak governments could not maintain the favorable budget positions.
} 
consequences of the hardening of financial discipline, and 5. the backwardness of the financial system. In our interpretation the process of the transformational recession was caused by the real economic structure inherited from the planned economy and the functional logic that could not be maintained under the circumstances of a market economy. This meant simply, that huge areas of industrial output were not competitive on world markets ${ }^{7}$. In an attempt to save production capacities from immediate collapse most governments continuously subsidized producers, who were still in state ownership and were the main employers. Subsidization was sooner or later given up, partly because it was not compatible with the newly introduced market economic logic and institutions since it crudely distorted competition, and partly because subsidized companies mostly failed to adjust activities to the new market economic framework (Szanyi 1996). Subsidization also seriously burdened the state budget.

The recession could be temporarily postponed by other policies such as the devaluation of the currency or the more gradual liberalization of the economy. Such policies were used extensively in the Czech Republic (Mertlik 1995), but the extended time lag was hardly used by companies for adjustment. The main reason for this was the slow hardening of the budget constraints and the disturbance of coordination mechanisms in the economy. There was no effective market force to induce adjustment policies, and state owned companies continued to rely on various kinds of paternalistic government support (from maintained trade barriers through currency devaluations to direct cash subsidies). As a result, huge debt burdens were accumulated throughout the economy. Debt was continuously refinanced by new loans and amended by new debt stemming from loss-making production in virtually all transition economies. The extent of this practice was different, depending on the length of the period of the survival of state paternalism and the extent of subsidization.

Instead of a long period of subsidization some countries applied "shock therapy". Market economic shocks were not accommodated, liberalization was quick and the state did not intervene to accommodate the results of the shocks either. The social costs of transition were of course compensated through the welfare system. This was more comprehensive in countries where the political arena was also characterized by competition (democracies). "Shock therapy" basically meant a quick and immediate departure from the old type of paternalistic state. This policy could be also supported by the newly established market economic institutions. With regard to the hardening of the budget constraints we can emphasize two of them: the two tier private banking system and market exit procedures. Both of these affect real economic activity through external control on activities. Loss making is not tolerated if creditors also have hard budget constraints and regularly monitor debtors and if effective exit procedures impose direct consequences in the form of market exit (liquidation). In an empirical survey Gray et al (1996) proved that the exceptionally harsh Hungarian bankruptcy law of 1992 resulted in an immediate and deep decline in debt arrears in the economy, as well in an effective reallocation of resources towards financially sound activities ${ }^{8}$.

\footnotetext{
7 The production of these goods was intended to serve protected markets cut off from world economic competition.

${ }^{8}$ Contrary to most bankruptcy regulations the 1992 Hungarian bankruptcy law called on debtors (instead of creditors!) to file for bankruptcy if they had overdue obligations. The "automatic trigger" launched an avalanche of bankruptcies resulting in a dramatic drop in debt arrears. Of course, negative effects in the form of a drop in output and increasing unemployment were also registered. From the point of view of hardening the budget constraints the law was rather successful.
} 
"Shock therapy" was also useful for establishing the credibility of economic policy. As has been described in an earlier paper (Szanyi 2002), the old imprint of the paternalistic state also had to be changed. Firms did not take threats of insolvency seriously while they could effectively rely on state accommodation. In Hungary, besides the harsh bankruptcy law, which was fully implemented, banking activity was also newly regulated, introducing new (and in other countries quite standard) prudential regulation. Banks were obliged by law to evaluate their asset portfolio and separate non-performing loans. They were also required to set aside adequate amounts as risk reserve, and to set up workout departments to handle insolvent clients. These activities were controlled by banking supervision. Thus, banks discontinued the refinancing of non-performing loans. Loss-making activities were discontinued since neither banks nor government extended new loans to refinance old debt or clearly loss-making activities.

The already accumulated debt was written off in the books of the commercial banks and the government as well. As a result, major banks still owned by the state became financially weak and were recapitalized by the state. Hence, the cost of the transformational crisis in the form of debt write-off was in the end largely paid by the state. The third pillar in the destruction of the old imprint was privatization. Government paternalism was also discontinued because the Hungarian government set up privatization policy goals that aimed at the sale of state enterprises (SOEs) in virtually all economic branches, including services and banking. SOE managers could no longer turn for support to the state as owner. Similar process evolved in the Czech Republic by the late 1990s.

The three pillars of microeconomic adjustment (bankruptcy, prudential regulation of banks and privatization) enabled the elimination of the old imprint of the paternalistic state. SOE managers had to start corporate adjustment processes if they wished to have a chance to remain in post (Szanyi 1996). In many cases they also took a role in the design of the privatization of "their" companies. In this way the credibility of the government and its policies was established. This credibility was also fully utilized in the stabilization efforts. The 1995 austerity measures which successfully limited budget deficit accumulation could be introduced because government policies seemed to be serious; i.e. no later accommodation was expected. On the other hand, their effect was also trusted. In fact, the government could substantially reduce foreign debt as well, using privatization revenues.

\section{Privatization patterns}

The fourth element of SLIP - privatization - was carried out in very different ways in CEEs 9 . The design and the actual policy steps were very much determined by general political considerations. As Freedman and Rapaczynski (1994) stated, privatization was primarily a tool for the redistribution of economic power which strongly affected political power relations. They explicitly formulated the claim that privatization should serve the breakup of the economic might of the communist nomenclature in order to make the process irreversible and end political turmoil. The idea effectively influenced privatization policies

9 The huge literature on privatization expands from the seminal conceptual work of Frydman and Rapaczynski (1994) through later assessments of the practice (e.g. Sutela, 1998) to applications with conclusions for latecomer transition countries (Rakova 2006). 
in many CEEs. But the question of how, and to whom, to transfer state property, was answered differently by the various privatization policies.

However, it was not only political considerations which influenced privatization. There was also a strong desire to use privatization to put an effective ownership pattern in place in (former) SOEs which could actively contribute to the adjustment and modernization of the companies (Szanyi 1996). The low level of efficiency, out-of-date technology and management practices, as well as the introduction of new markets required substantial investments in technology, marketing and managerial know-how. The accumulation of these elements started at a rather clumsy speed in SOEs, since they lacked the necessary capital for investment (they were chronically undercapitalized, and many of them were seriously indebted). Moreover, they also lacked the necessary knowledge and experience. What is more, they did not have much time to deal with the adjustment tasks. The transition process delivered important changes in organization, book-keeping and taxation; managers also had to deal with ongoing privatization issues. The business considerations and tasks of privatization were therefore frequently pushed into the background.

A further important aspect of the privatization policy was the outside pressure on governments. One element of SLIP was that international financial institutions and other parties urged quick and effective privatization. The EBRD Transition Reports, for example, evaluated transition economies' "transition performance" also using the degree of privatization (mainly the share of the private sector in GDP) as an important progress measure. Sometimes "package deals" were offered to governments. Financial support for institution building was treated in one package with the request to extend privatization in certain economic branches or companies. Governments could not always escape from the pressure. In the case of Hungary the aim of reducing accumulated foreign debt also contributed to the choice of privatization methods. The government wanted to receive quick cash revenue from privatization.

There were four major types of privatization methods, the sales method, voucher privatization, ESOP and insider privatization. Other policies such as restitution (in kind or in other forms) or bankruptcy of SOEs also affected elements of state property. The dominant policies were the first two - sales and vouchers - although virtually all transition economies applied a mixture of all four methods with different emphasis. The resulting ownership structure of the economy, the identity of the actual owners, and new owners' ability to adjust and modernize companies did not show a clear preference for any of the privatization models.

The sales method was chosen as the primary tool mainly because of the government's desire to reduce foreign debt by using revenues from the privatization process. First manufacturing and trade, and later services and banks were sold, mainly to foreign investors, who were in a superior bidding position compared with domestic investors. Big business' most lucrative segments were sold to multinational companies; the rest were bankrupted and sold to domestic owners almost as scrap ${ }^{10}$. By the mid 1990's privatization had already become the most important channel of foreign direct investments (FDI) in Hungary. The sales contracts were usually amended with clauses containing requirements for future employment, new investments, etc. On the other hand, foreign investors usually

10 Bankruptcies were often suspiciously fraudulent. Incumbent management could often buy out valuable assets at a low price. In many cases the assets "privatized" in this way were later run quite efficiently (Szanyi 2001). 
only bought segments of larger SOEs, which they could insert into their international production and distribution networks. Also, in most cases environmental cleanup - in the case of banks the cleaning of the asset portfolio - was necessary before SOEs could be sold. This reduced state revenues quite substantially. The newly acquired facilities were then quickly rebuilt, equipped and inserted into the international networks (Szanyi 1999). Firms privatized to foreign investors became (and remained) the flagship companies of Hungarian manufacturing with very high levels of productivity and cutting edge technologies.

The other main type was voucher privatization. This method was also used in all transition economies (including Hungary). The main aim was to strengthen domestic owners, a kind of new bourgeoisie with an even distribution of property rights among citizens. Czechoslovakia was the most important pioneer of this method. In the Czech Republic it was consequently continued after the 1992 breakup of the former country, while in Slovakia other methods, mainly forms of insider privatization, gained momentum ${ }^{11}$. The original idea was to distribute ownership coupons almost for free among citizens which could be exchanged via secondary capital markets to real stocks in privatized companies. Designers hoped not only that many people would express an interest and gamble with shares, but that in this way capital markets would also be boosted.

The results were at most mixed. Not many Czech citizens became wealthy new owners, since most of them not only transferred their coupons to the so called "privatization investment funds", but effectively sold them for cash, even before the coupons were exchanged for corporate shares. Hence, the "real owners"12 of the Czech SOEs' became the funds, not citizens or coalitions of them. Thus, the primary political goal was not achieved. Unfortunately, the economic (business) goal was not achieved either. On the contrary, the opportunistic behavior of incumbent managers was further fuelled, since no effective owners' control evolved. 5 out of 7 main investment funds were funded by large stateowned commercial banks. The process was therefore described by the later Minister of Finance Pavel Mertlik as a process "from public ownership to public ownership in five years" (Mertlik 1995). Needless to say, the coincidence of two main external controller positions (owner and creditor) further fuelled the opportunistic behavior of managers.

The result was a continuous rolling over of debt by banks, and, by the steady accumulation of losses in the quasi privatized companies, a substantial increase of state debt. Nonperforming assets were allocated to a separate state bank, the Consolidation Bank, which, on the other hand, was not directly linked to the state budget. Therefore, increasing state debt was hidden. This was a basic element of the "Czech miracle" during the 1990s, an exceptionally high degree of privatization, a seemingly balanced state budget and good external competitiveness (this was based on a drastic one-off devaluation of the Czech currency). In the background no structural change, declining competitiveness and a steady (albeit covert) increase in state debt occurred. The hidden tensions broke out in the late 1990s when a second transitional crisis swept through the Czech economy removing many of the ailing manufacturing firms. Bad debt had to be written off, just as in Hungary 5 years earlier, in order to clean commercial banks' portfolios before their privatization. By this

\footnotetext{
11 The same happened in other ways in Russia and in many other CIS countries.

12 A term which was frequently used in Hungarian papers in 1988-90 when expressing the desire to find owners for SOEs who were responsible and enjoyed ownership licences to the full extent, and who could then initiate adjustment and restructuring.
} 
time the Czech governments had not repeated the voucher privatization scheme involving the remaining state property, but had switched to the sales method.

In Slovakia's insider privatization corruption and favoritism was more pronounced. New owners tended to be chosen deliberately from the supporters of the ruling party (mainly the Meciar clan). In other countries too, although less explicitly, privatization policies gave way to favoritism in more or less direct forms. Hungary is no exception either. Thus, privatization became a kind of battlefield among political parties who wanted to redistribute parts of state property among (business) persons loyal to them. Oppositional parties used to blame governments for non-transparent privatization deals, although when in power they themselves used the same methods to strengthen their business backyard. While favoritism can be observed in more developed countries as well, the main difference is more transparency, the effective role of watchdog institutions (which are absent in transition economies), and the stronger political consequences of open scandals.

In Russia, the initial voucher privatization scheme was turned into insider dealing. The Russian privatization process was designed by neoliberal advisors and young Russian economists focusing on speed rather than on real effects. The original method was based on the employee stock ownership plan (ESOP), a method known from developed welfare states which aimed at increasing incentives for employees in strengthening collective action through shared ownership as well ${ }^{13}$. Ownership rights were distributed among the employees and managers of firms. Advisers could quickly complete their tasks through another formal solution of the problem of ownership change. Corporate shares were not very valuable, since the transformational recession hit Russia especially hard (with output drops of 50$60 \%$ ). Shares could be accumulated very cheaply by individuals (mostly senior managers of firms). Those lucky managers who were employed in more prosperous branches (the oil and gas industry for example) could easily increase their ownership share. The process was even encouraged by preferential credits from the state owned banks. Corruption was very widespread in the process. When energy prices started to skyrocket and the Russian economy became stabilized, the value of the cheaply acquired ownership shares increased tremendously, bringing huge wealth to the new owners (oligarchs). They then soon developed close ties with political parties, forming a solid basis for crony capitalism ${ }^{14}$.

Stark (1996) drew the general conclusion after examining the various privatization models of the CEE that property rights did not really change hands, instead there was a kind of exchange and reallocation of assets among the same players. He therefore called the new ownership pattern "recombinant property". While this statement seems to be all too general, since foreign ownership, for example, does not fit into this logic, it is true that in most transition economies the main political goals of privatization could not be achieved. The economic power of incumbent management and (mainly second line) communist party members remained in place. Privatization could not destroy it in the way Frydman and Rapaczynski (1994) envisaged and claimed. This fact, as well as the evolving cronyism in the CEE may be an important factor in the capitalist model of Central and Eastern Europe.

13 The Yugoslav self-governing enterprise form was also a similar concept.

14 The topic will be covered more in detail later. 


\section{Evolving new structures: foreign direct investment}

One of the main differences between the CEE and CIS countries' capitalist models is the level of foreign investments. In the CEE only Slovenia showed some interest towards foreign investors. Relatively low FDI levels (especially in manufacturing) in Romania and Bulgaria are catching up. On the other hand, CIS countries deliberately avoided a substantial inflow of foreign capital. This unfriendly policy then triggered a substantial caution on the side of the investors too: they did not rush to invest. Nevertheless, there is also foreign interest in the more important CIS countries, in Russia and the Ukraine, for example, but they concentrate on services and the banking sector, and are practically excluded from activities regarded in any way as of strategic importance. Another interesting feature is that many Hungarian, Polish and Czech companies invested in the CIS, but their overall share in total FDI stock is small. Hence, it is important to differentiate among transition economies in terms of their openness and exposure to FDI. In the following we deal primarily with CEE economies where FDI plays an important role.

Many believe that the essence of SLIP was the creation of favorable (uniform) conditions for the expansion of multinational business. While it is not quite clear if this was the single most important driver of the process of "setting up the rules of the game", it is quite obvious that SLIP included measures that enhanced FDI. This is especially true for transition economies, since in these countries creating conditions of "a level playing field" meant an immediate confrontation between local business which were handicapped in many ways and large international competitors. Competition even in the simplest form of imports soon drove many local companies out of the markets. But multinational firms captured not only CEE markets but much of the local business inputs in the form of local investments (location advantages ${ }^{15}$ ). There has been an ongoing debate whether integration into the world economy was also possible via endogenous business. Critics of dependence on foreign firms frequently cite current Polish business development, where an impressive number of local firms became international players.

There were two main channels of FDI inflows in transition economies: privatization and greenfield investments. It is important to emphasize that in virtually all CEEs both channels were used, and many large scale investments in manufacturing, services and the financial sector were carried out in this way. The pioneering role was played by Hungary during the mid- and late 1990s (see the previous section on privatization). But other CEEs soon caught-up by selling important SOEs at the turn of the millennium. The other form of FDI, greenfield investments, has been carried out in large numbers during the past 15 years in all CEEs including Romania and Bulgaria. Foreign firms play an important, and in the case of Hungary, Slovakia and the Czech Republic, a determining role. Their share in the production of GDP, employment, investments and exports is large and growing with time. During the crisis of 2007-9 they usually played a stabilizing role, despite the fact that their production also shrunk (they did not close down).

Where their influence was larger foreign investments have created a completely new economic structure. For example, the Hungarian electronics and automotive sectors have developed in parallel with foreign investments. Foreign firms dominate both branches. Multinational brand-owners' investments were followed by their traditional suppliers'

15 We use here the terms of John Dunning's well known "Eclectic Theory" of FDI. 
investments in the new location. This was due to their close technological cooperation which required spatial concentration. But most local companies of the two branches are also linked to multinationals at various levels of cooperation. The local supplier network development of the multinationals sometimes includes the teaching and technological upgrading of local firms. The structure of CEE industries was completely altered and inserted into the global labor division, the multinational companies' network. This change can be also measured by macroeconomic measures such as foreign trade data. It is not only the commodity pattern and relational structure which have changed over the past 25 years, but the share of intra firm trade has also increased to high levels, which clearly shows the important role of multinational networks' activities.

FDI inflow in CEE (EUR million) and per capita inflow

Table 1 and stock 2011 (EUR)

\begin{tabular}{|l|c|c|c|}
\hline & FDI Inflow & Per capita inflow & Per capita stock \\
\hline Bulgaria & 1341 & 182 & 5018 \\
\hline Czech Republic & 3880 & 369 & 9175 \\
\hline Hungary & 2999 & 301 & 6558 \\
\hline Poland & 9500 & 248 & 3712 \\
\hline Romania & 1920 & 101 & 2858 \\
\hline Slovakia & 1542 & 283 & 7339 \\
\hline Slovenia & 791 & 386 & 5710 \\
\hline
\end{tabular}

Source: Hunya (2012)

In an earlier paper we summarized the potential benefits for host economies stemming from FDI (Szanyi 1999). Both direct and indirect forms of positive effects may occur, but they are rather difficult to measure. Direct effects on employment, the application of new technologies, access to export markets, and the introduction of up-to-date management methods are clearly demonstrated. All these, but especially new knowledge, is also transferred to other market players, a major form of indirect spillover effects. Strong competition can force local competitors to improve their performance, but there is also a chance that they cannot stand the competition and will be crowded out of the market (which is a negative spillover effect). 
Table 2

Inward FDI stock in CEE by economic activities 2010 (share in \%, NACE Rev 1 class.)

\begin{tabular}{|l|c|c|c|c|c|c|c|}
\hline & $\begin{array}{c}\text { Bulga- } \\
\text { ria }\end{array}$ & $\begin{array}{c}\text { Czech } \\
\text { R. }\end{array}$ & $\begin{array}{c}\text { Hun- } \\
\text { gary }\end{array}$ & $\begin{array}{c}\text { Po- } \\
\text { land }\end{array}$ & $\begin{array}{c}\text { Roma- } \\
\text { nia }\end{array}$ & $\begin{array}{c}\text { Slova- } \\
\text { kia }\end{array}$ & $\begin{array}{c}\text { Slove- } \\
\text { nia }\end{array}$ \\
\hline A+B Agriculture & 0.5 & 0.2 & 0.4 & 0.5 & 1.0 & 0.2 & 0.1 \\
\hline C Mining & 0.7 & 2.8 & 0.3 & 0.2 & 4.0 & 1.1 & 0.1 \\
\hline D Manufacturing & 17.3 & 32.0 & 24.8 & 31.8 & 31.5 & 34.5 & 26.9 \\
\hline $\begin{array}{l}\text { E Electr. gas and water } \\
\text { supply }\end{array}$ & 5.3 & 8.0 & 5.5 & 4.1 & 5.5 & 13.3 & 3.0 \\
\hline F Construction & 7.6 & 1.4 & 0.8 & 2.5 & 3.7 & 1.2 & 0.8 \\
\hline G Trade, repair & 13.5 & 9.9 & 12.7 & 15.9 & 12.2 & 11.0 & 13.1 \\
\hline H Hotels, restaurants & 1.7 & 0.5 & 0.4 & 0.4 & 0.4 & 0.2 & 0.2 \\
\hline $\begin{array}{l}\text { I Transport, } \\
\text { Communication }\end{array}$ & 10.8 & 5.2 & 7.4 & 5.8 & 6.8 & 4.4 & 3.4 \\
\hline J Financial intermed. & 17.8 & 20.4 & 9.5 & 18.6 & 20.5 & 20.9 & 40.4 \\
\hline K Real estate & 23.4 & 16.2 & 30.8 & 17.6 & 13.7 & 12.3 & 11.5 \\
\hline L Public admin. & 0.0 & 0.0 & - & - & - & - & - \\
\hline M Education & 0.0 & 0.0 & - & - & - & - & 0.0 \\
\hline N Health & 0.0 & 0.2 & - & - & - & 0.2 & 0.0 \\
\hline O Other commun. act & 0.6 & 1.1 & - & - & - & 0.6 & 0.4 \\
\hline
\end{tabular}

Source: Hunya (2012)

Table 3

Outward FDI stock of CEE 2011 (EUR million)

\begin{tabular}{|c|c|c|c|c|c|c|}
\hline Bulgaria & Czech R. & Hungary & Poland & Romania & Slovakia & Slovenia \\
\hline 1312 & 11956 & 18439 & 28000 & 1149 & 3000 & 5519 \\
\hline
\end{tabular}

Source: Hunya (2012)

In a measurement attempt we found evidence for the prevailing positive indirect spillovers at the second and third tier suppliers of the multinational firms (Makó et al 2011). Other scholars did not find convincing evidence ${ }^{16}$.

${ }^{16}$ For an overview of literature on this topic see Szanyi (1999). 
Potential positive externalities may reach supplier companies, whose contribution is essential in the value chain of multinational production. There are several reasons for the unexpectedly sluggish local supplier network development. Most importantly, local companies' preparedness is low, and in many cases there are no potential local suppliers at all, or they cannot work at the required accuracy, technological level and reliability. But existing potential is not fully utilized either. Whenever local affiliates of multinational firms are in a subordinate status and have no decision license in important questions local supplies always fail to develop (Antalóczy et al 2011).

\section{The current status of the CEE}

The main aim of this study was to work out a positive definition for the CEE capitalist development model. In this section we would like to provide some evidence that despite the many differences in actual transition processes the longer term development path of CEE economies has become rather similar. As far as the macroeconomic situation is concerned, the transitional recession was overcome in the whole of the CEE and GDP production reached the 1989 level in the second half of the 1990s. However, these economies underwent fundamental structural changes. The former heavy industry-biased structure changed, the share of manufacturing industry declined and the share of services increased to the extent of the developed market economies of Europe. There were no major differences in this regard, though the collapse of the former socialist industrial base gave way to more foreign investments in the Visegrad countries, ${ }^{17}$ than in Romania or Bulgaria, where the share of industrial production remained at a lower level. Economic restructuring was very much driven by foreign investments, which remained at low levels in manufacturing industry in the two latter countries ${ }^{18}$.

Foreign trade used to be an important driver of the CEE economies, since, with the exception of Poland, they all are small open economies. Their openness increased in the transition process. This is not only because large multinational companies' international cooperation networks automatically boost trade figures due to their deep specialization in components and parts. Local companies also started to actively participate in foreign trade. Many of them even started exporting capital (Antalóczy - Eltetö 2002; Kalotay and Sass 2010; Hunya 2012). Thus, the CEE became an integrated part of the global world economy with strong ties to international production networks. A high level of openness, the important role of foreign companies, dependence on foreign markets on the export side and on energy imports coming from the CIS (mainly Russia) form the external environment of these economies. The relatively larger domestic market of Poland gives this country a little more room for maneuver, but the Polish economy is also strongly linked with the global economy. This economic structure gave rise to an impressive increase in productivity, which was in many years faster than increases in wages. Unit labor costs remained rather low compared to developed market economies (Szanyi 2003). This helped

\footnotetext{
17 These are Poland, the Czech Republic, Slovakia and Hungary.

18 The two countries opened up to FDI rather late, when major multinational companies had already established their regional affiliates in the Visegrad countries. Nevertheless, market driven service companies also invested in Romania and Bulgaria extensively.
} 
to boost international competitiveness. In the case of Hungary and the Czech Republic a trade surplus was achieved during the past 5 years (Túry - Vida 2012).

Table 4

Miscellaneous macroeconomic data for the CEE

\begin{tabular}{|l|c|c|c|c|c|c|c|}
\hline & Bulgaria & Czech & Hungary & Poland & Romania & Slovakia & Slovenia \\
\hline $\begin{array}{l}\text { GDP per capita PPP US\$+ } 2011 \\
\text { (rank 1-148) }\end{array}$ & $\begin{array}{c}13800 \\
(92)\end{array}$ & $\begin{array}{c}27400 \\
(49)\end{array}$ & $\begin{array}{c}19800 \\
(62)\end{array}$ & $\begin{array}{c}20600 \\
(60)\end{array}$ & $\begin{array}{c}12600 \\
(97)\end{array}$ & $\begin{array}{c}23600 \\
(57)\end{array}$ & $\begin{array}{c}29000 \\
(46)\end{array}$ \\
\hline $\begin{array}{l}\text { Government revenue as \% of } \\
\text { GDP* 2011 (2007) }\end{array}$ & $\begin{array}{c}33.1 \\
(40.9)\end{array}$ & $\begin{array}{c}40.3 \\
(40.3)\end{array}$ & $\begin{array}{c}52.9 \\
(45.6)\end{array}$ & $\begin{array}{c}38.5 \\
(40.3)\end{array}$ & $\begin{array}{c}32.5 \\
(35.3)\end{array}$ & $\begin{array}{c}44.5 \\
(42.4)\end{array}$ & $\begin{array}{c}33.4 \\
(32.4)\end{array}$ \\
\hline FDI stock as \% of GDP 2011++ & 89 & 58 & 60 & 38 & 38 & 53 & 31 \\
\hline Exports as \% of GDP 2011++ & 63 & 75 & 92 & 42 & 22 & 89 & 72 \\
\hline Imports as \% of GDP 2011++ & 65 & 71 & 85 & 43 & 29 & 86 & 71 \\
\hline Industry v. a. \% of GDP 2011++ & 31 & - & 31 & 32 & 25 & 35 & 32 \\
\hline Services, v. a. \% of GDP 2011++ & 63 & - & 65 & 65 & 68 & 61 & 66 \\
\hline
\end{tabular}

Sources: * :http://epp.eurostat.ec.europa.eu ++:World Bank

+ https://www.cia.gov/library/publications/the-world-factbook/

Another important macroeconomic feature of CEE countries is the relatively smaller role of the state in the redistribution of GDP. The difference does not seem to be very large when compared to the EU average, but is significantly lower than most continental countries, and much lower than in the Scandinavian economies ${ }^{19}$. The current crisis showed that most models of the welfare state need some rethinking. Sapir (2006) showed that most EU countries welfare systems were inefficient and in some ways also dysfunctional (they did not limit inequalities). The problems became more acute in the 2007/9 crisis. CEE countries are in this regard in a better position. Though the decade-long rhetoric on catching-up with living standards and welfare has not yet changed (this target was just postponed for the polity), CEEs are in an easier situation than more developed EU-members because less welfare spending must be cut.

Debates on the Hungarian welfare system revealed the fact that services were oversized compared to the capacities of the state (Kornai 1992). Of course, levels of welfare services have always been lower than in any of the EU-15; nevertheless, the growth of the Hungarian economy and of budget revenues has not been quick enough to reduce the budget gap in social spending. Therefore an effective (involuntary) cut in spending has already been started. Other transition economies faced similar problems, though we could observe some examples of better management. In Slovakia, for example, the overall size of the budget was successfully cut by ten percentage points. Redundant services were eliminated. Another example is the Polish health care system, which was successfully reorganized.

19 The most influential paper on the types of welfare systems is that of Sapir (2006). 
Miscellaneous social data for the CEE

Table 5

\begin{tabular}{|l|c|c|c|c|c|c|c|}
\hline & Bulgaria & Czech & Hungary & Poland & Romania & Slovakia & Slovenia \\
\hline Human Development Index*2011 & $\begin{array}{c}0.771 \\
(55)\end{array}$ & $\begin{array}{c}0.865 \\
(27)\end{array}$ & $\begin{array}{c}0.816 \\
(38)\end{array}$ & $\begin{array}{c}0.813 \\
(39)\end{array}$ & $\begin{array}{c}0.781 \\
(50)\end{array}$ & $\begin{array}{c}0.834 \\
(35)\end{array}$ & $\begin{array}{c}0.884 \\
(21)\end{array}$ \\
\hline Labor participation rate 2010+ & 54 & 59 & 51 & 56 & 56 & 59 & 59 \\
\hline Unemployment 2010+ & 10.2 & 7.3 & 11.2 & 9.6 & 7.3 & 14.4 & 7.2 \\
\hline $\begin{array}{l}\text { People at risk of poverty or social } \\
\text { exclusion** 2010+ }\end{array}$ & $\begin{array}{c}3145 \\
(41.9)\end{array}$ & $\begin{array}{c}1495 \\
(14.3)\end{array}$ & $\begin{array}{c}3051 \\
(30.5)\end{array}$ & $\begin{array}{c}10409 \\
(27.2)\end{array}$ & $\begin{array}{c}8890 \\
(41.6)\end{array}$ & $\begin{array}{c}1118 \\
(20.7)\end{array}$ & $\begin{array}{c}366 \\
(17.8)\end{array}$ \\
\hline Ease of doing business (1-183)+ & 59 & 64 & 51 & 62 & 72 & 48 & 37 \\
\hline $\begin{array}{l}\text { Corruption reception index (1-10) } \\
2010+\end{array}$ & $3.3(86)$ & $4.4(57)$ & $4.6(54)$ & $5.5(41)$ & $3.6(75)$ & $4.0(66)$ & $5.9(35)$ \\
\hline $\begin{array}{l}\text { Shadow economy as \% of GDP } \\
2011^{* * *}\end{array}$ & 32.3 & 16.4 & 22.8 & 25.0 & 29.6 & 24.1 & 16.0 \\
\hline $\begin{array}{l}\text { Income inequalities (Gini coeff.) } \\
2008++\end{array}$ & - & 0.268 & 0.291 & 0.372 & - & 0.268 & - \\
\hline
\end{tabular}

Sources: $\quad{ }^{*} h t t p: / / h d r . u n d p . o r g / e n / m e d i a / H D R \_2011 \_E N \_C o m p l e t e . p d f$

**.http://epp.eurostat.ec.europa.eu

*** Schneider, F. (2011) +:World Bank++: European Commission (2010)

It seems that the main problem of CEE countries in this regard is the labor-saving character of their post-communist economic growth path. Productivity and output increased tremendously, but not employment. In some countries activity rates are very low, and unemployment is also high. Society has become more and more divided. Those who are employed (a large share of employment is bound to the public administration) have been able to increase living standards, meanwhile people on pensions and the longterm unemployed have not been able to maintain theirs. The proportion of people at risk of poverty has increased and reached a rather high level in most CEE countries. As a consequence many have migrated to more developed countries of the EU in search of jobs. The once high quality labor force of these countries (see the good rankings of the human development index) has become scarce, because its simple reproduction is not guaranteed. The vicious circle of low employment, less social spending, declining labor force reproduction, and even fewer job opportunities has evolved over time. It is more severe in Bulgaria and Romania, but is also being felt in Hungary and Poland. The CEE's main social problem is therefore to find an economic development path that creates more jobs (or spreads work more evenly among employees) so that out-migration is reduced, more income is generated, and it is distributed more evenly.

The relatively higher share of the shadow economy in most CEE countries is closely connected to thelow employment situation. It also affects budget revenues quite substantially. In fact, there is a third section of CEE societies, those who have regular income and are not threatened by poverty. But incomes in the shadow economy are by definition not taxed. Therefore many "entrepreneurs" and even more who work for them do not contribute to 
the full extent of their incomes to the budget, but receive full services. Similar effects are caused by regular tax evasion (under-reporting of sales revenue). The most widespread form of tax evasion is not billing sales and thus "economizing" on value added tax. Citizens do not even know that they themselves are accomplices of tax evasion when not asking for the receipt in a shop. A vicious circle has evolved in this respect too. The poorer the citizens become (because budget cuts limit both their incomes and also their chances of future employment), the more they feel forced to take the opportunity of cheap solutions (tax evasion, the purchase of low quality goods from uncontrolled imports, etc.) which further increases the shadow economy and reduces budget revenues.

\section{State paternalism and crony capitalism in the CEE}

Current forms of crony capitalism have their origins in CEE and CIS economies' state paternalism of the pre-transition period. The term 'state paternalism' was developed for, and applied to, command economies by Kornai (1980). It described the relationships between state bureaucracy and company management. In the command economy companies did not take responsibility for decisions; in fact they had no freedom to decide on important questions but had to fulfill commands sent to them by the institutions of state bureaucracy. However, since state bureaucrats and company leaders both worked under the political control of the communist party, their relationships were characterized by informal bargaining over the planning targets. As a consequence, the relationship between state and company leaders became rather informal. The classic roles of managers and owners did not apply. This informal relationship with the final risk-taking of the state (the communist party) gave way to opportunistic behavior among company leaders. They could effectively use their insider information in the companies in the bargaining process during the preparation of economic plans. On the other side, the communist party-governed state took responsibility for the economy and society and always corrected and intervened when individual companies, branches or the economy as a whole, got into trouble ${ }^{20}$.

Company leaders inherited state paternalism from the command economy and also relied on it when the transformational recession hit transition economies. Incumbent managers argued that many of their problems were inherited and not created by them, therefore they should not be made responsible for past decisions, and neither should "their" companies bear the financial consequences. Surviving state paternalism intervened, state banks rolled old debts over, governments bailed out loss-making firms. The paternalistic attitude of CEE governments remained in place virtually up till the moment SOEs were privatized.

As was argued earlier political parties considered privatization as a means to complete political transformation, and to create and strengthen business partners loyal to them. Favoritism ploughed the privatization process. The creation of loyal clients was not only important because of the self-interest of individual politicians, but also because the financing of political parties and activities has not been regulated properly. Support from business

20 Mihályi (2003) compared company leaders' attitudes in command economies and in companies with management share ownership in the framework of corporate governance. He found similarities because in both case leaders became also owners, "insider owners" in one or another sense. In both systems "insider ownership" deteriorated company efficiency because it gave way to rent seeking behavior on the part of leaders (see the famous scandals of ENRON, World Com, Parmalat, and other frauds). 
and from state controlled companies contributes largely to the financing of political parties. Unfortunately, this type of financing is not effectively controlled, unlike in more developed democracies. In return for their support companies may expect various further forms of favoritism. This type of interplay between polity and business is called crony capitalism.

Cronyism is in place in all market economies, but it may be kept under control by the effective watchdog institutions of the society. CEE societies are not yet strong and organized enough to establish powerful control institutions. Hence, cronyism is especially strong in these countries. Russia and the Ukraine are perhaps the most discussed examples of crony capitalism. In these two countries even the most basic institutions of democracy are rather weak. But CEE countries are not exempt from rather crude examples of cronyism expanding into bribery and corruption as well.

There is a special form of crony capitalism, which is present in the CEE economies, and is different from other countries. The "classic" form is dominated by business. In LatinAmerica or the Far-East it has been business that has approached and directed polity in this dubious relationship. This is called "state capture". The state, i.e. governments, are controlled and influenced in their decisions by strong business groups. In exchange for support for political institutions (election campaigns) business groups lobby for regulations preferential for them, and for exceptional treatment. In the classic case big business supports all political parties, so that preferences prevail even in the case of eventual changes in government.

However, in CIS and perhaps also in CEE countries the relationship is often reversed. "Business capture" (Yakovlev 2006) means that governments and political parties (political interest groups) regard the economy as a hunting ground. A strong state, i.e. strong government, may use power to rob business, not only those who dared to oppose government decisions in any way, but also those who tried to keep their distance from the polity. Political power may be used as tool for favoritism, but also for repression. Yakovlev (2006) convincingly argues that the Putin government effectively turned the tide and crushed opposing business circles using the might of the then already stronger state (see the fate of the oligarch Khodorkovski). The capturing state can either extract something illegally from a privatization or any other action carried out by big business and use it for repression, or simply drop the firm from the list of favored companies. But business capture also means the strengthening and recreation of state ownership, the direct intervention of the state in business (see the Gasprom story in Russia). In this way, the business capture form of crony capitalism seems to turn back in some ways to the original departure point, the paternalistic state.

\section{Conclusions}

The economic model of Central and Eastern Europe does exist, although research has not yet been able to positively describe its values. In this paper we have tried to summarize the existing literature and give an overview of the transition process of the CEE which fundamentally shaped the type of capitalism in the region. Further research is required to elaborate more details. This paper tried to give a draft overview of the positive values. They partially stem from geographic, historical and social similarities (e.g. they are small open economies). Other features of the model were developed during the transition process (e.g. the role of FDI, problems of job creation). A third important element comes from the interplay of polity and business. It is not just the emergence of cronyism, but the 
establishment of business capture. Some of these factors have already been described and evaluated in the VoC literature. Nevertheless, the co-influence and parallel development of the main features has not been elaborated. This may be the main line of future research on the topic.

\section{References}

Amable B.(2003): The diversity of modern capitalism. Oxford: Oxford University Press.

Antalóczy K. - Éltetö, A. (2002): Outward Foreign Direct Investment in Hungary - Motivations and Effects. IWE Working Paper no.125, April.

Antalóczy, K. - Sass, M. - Szanyi, M. (2011): Policies for attracting foreign direct investment and enhancing its spillovers to indigenous firms: The case of Hungary. In: Rugraff E. - Hansen M.W. (eds.): Multinational Corporations and Local Firms in Emerging Economies. Amsterdam University Press:181-210.

Berrou, J.-P. - Carrincazeaux, C. [2005]: La diversité des capitalismes et les pays d'Europe centrale et orientale. Groupement de Recherches Economiques et Sociales. Cahiers du GRES, 18. http://cahiersdugres.ubordeaux4.fr/2005/2005-18.pdf

Blanke, T. - Hoffmann, J. (2008): Towards a European social model preconditions, difficulties and prospects of a European social policy, International Journal of Public Policy, Vol. 3, Nos. 1/2:20-38.

Bohle, D. - Greskovits B. (2007): Neoliberalism, embedded neoliberalism and neocorporatism: towards transnational capitalism in Central-Eastern Europe. West European Politics 30:443-366.

Cernat L. (2006): Europeanization, varieties of capitalism and economic performance in Central and Eastern Europe. Geneva: ILO 9-56.

Csaba L. (2007): Átmenet vagy spontán rendetlenség? Közgazdasági Szemle LIV. Évf:757-773.

European Commission (2008): Industrial relations in Europe 2008. Brussels, EC.

European Commission (2010): Why socio-economic inequalities increase? Facts and policy responses in Europe. EC DG for Research Communication Unit.

EBRD (1999): Transition Report 1999. Ten years of transition. EBRD, London.

Farkas B. (2011a): The Central and Eastern European model of capitalism. Post-Communist Economies London, vol. 23. no. 1. p. 32.

Farkas B. (2011b): A közép-kelet-európai piacgazdaságok fejlödési lehetőségei az Európai Unióban. Közgazdasági Szemle 58. évf. 5:412-429.

Fischer, S. - Sahay R. (2000): The Transition Economies After Ten Years. NBER Working Paper No. 7664.

Frydman, R. - Rapaczynski, A. (1994): Privatization in Eastern Europe: Is the State Withering Away? CEU Press, Budapest.

Gerschenkron, A. (1962): Economic backwardness in historic perspective, a book of essays. Cambridge Ma. Belknap Press.

Gray, C. - Schlorke, S. - Szanyi, M. (1996): Hungary's Bankruptcy Experience, 1992-93. The World Bank Economic Review, Vol. 10, No. 3:425-450

Hall P.A. - Soskiece D. (eds.) (2001): Varieties of Capitalism. The Institutional Foundations of Comparative Advantage. Oxford: Oxford University Press.

Hofstede G. (1980): Motivation, Leadership and Organization: Do American Theories Apply Abroad? Organizational Dynamics, Summer:42-63

Hofstede G. - Bond M.H. (1988): The Confucius Connection: From Cultural Roots to Economic Growth. Organizational Dynamics, 16:4-21.

Hunya, G. (2012): Short-lived recovery. wiiw Database on Foreign Direct Investment in Central, East and Southeast Europe. WIIW.

Hunya, G. - Sass M.(2005): Coming and Going: Gains and Losses from Relocations Affecting Hungary. WIIW Research Report No. 323.

Kalotay, K. - Sass, M. (2010): Outward FDI from Hungary and its policy context. Columbia FDI Profiles, June 24. Vale Columbia Center.

King L.P. (2007): Central European capitalism in comparative perspective. In: Hancké B. - Rhodes M. Thatcer M. eds: Beyond varieties of capitalism. Conflicts, contradictions and complementarities in the European economy. Oxford: Oxford University Press. 
Kornai, J. (1980): Economics of Shortage. North Holland Publ. Co.

Kornai, J. (1992): The postsocialist transition and the state: Reflections in the light of Hungarian fiscal problems. American Economic Review, Papers and Proceedings, May, 82/2:1-21.

Kornai, J. (1994): Transformational Recession: The Main Causes. Journal of Comparative Economics 19(3):39-63.

Kornai, J. (2000): What the Change of System From Socialism to capitalism Does and Does Not Mean. Journal of Economic Perspectives Winter, 14(1):27-42

Landesmann, M.(2000) : Structural change in the transition economies 1989-1999. Economic Survey of Europe, Vol. 2, Nummer 3, Seite(n):95-117.

Lane D. (2007): Post-state socialism: a diversity of capitalism? In: Lane D. - Myant M. eds: Varieties of capitalism in post-communist countries. New York: Palgrave MacMillan:13-39.

Mertlik, P. (1995): Czech Privatization: from Public Ownership to Public Ownership in Five Years? Prague Economic Papers, 4:321-336.

Makó, Cs. - Csizmadia, P. - Illéssy, M. - Iwasaki, I. - Szanyi, M. (2011): Organizational Innovation and Knowledge Use Practice: Cross-Country Comparison. IER Discussion Paper No. B38, Institute of Economic Research of Hitotsubashi University, Tokyo, January.

Mihályi, P. (2003): A vállalatvezetök motivációja a szocializmusban és a piacgazdaságban - régi és új tapasztalatok. (Corporate leaders' motivation in socialism and in capitalism - old and new experiences) Közgazdasági Szemle, 50. évf. 5:428-449.

Rakova, E. (2006): Privatization Experience of Some CEE and CIS Countries. Lessons for Belarus. ICEG Working Paper No. 29.

Rodrigues M.J. (ed.)(2009): Europe, globalization and the Lisbon agenda. Cheltenham: Edward Elgar.

Roland, G.(2000): Transition and Economics, Politics, Markets and Firms. Cambridge, Mass.-London, MIT Press.

Sapir, A. (2006): Globalization and the reform of European social models. Journal of Common Market Studies Vol. 44, No. 2: 369-390.

Schneider, F. (2011): The Shadow Economy in Europe. A.T. Kearney.

Stark, D. (1996): Recombinant Property in East European Capitalism. American Journal of Sociology, 101(4):993-1027.

Stiglitz, J. (1999): Whither Reform? Ten Years of Transition. Annual Bank Conference on Development Economics, Washington D.C.

Sutela, P. (1998): Privatization in the Countries of eastern and Central Europe and the Former Soviet Union. UNU/WIDER Working Paper No. 146.

Szanyi, M. (1996): Adaptive Steps by Hungary's Industries During the Transition Crisis. Eastern European Economics. 34 (5), September-October:59-77.

Szanyi, M. (1999): The role of FDI in restructuring and modernization: an overview of literature. In G. Hunya (ed.): Integration through Foreign Direct Investment - Making Central Europe Competitive (Cheltenham: Edward Elgar):50-80.

Szanyi, M. (2001): Life After Death: Is It Efficient to Reallocate the Assets of Financially Distressed Firms? IWE Working Paper No. 120. October.

Szanyi, M. (2002): Bankruptcy regulations, policy credibility and asset transfers in Hungary. IWE Working Paper No. 130. October.

Szanyi, M. (2003): An FDI-based development Model for Hungary - New Challenges? IWE Working Paper no. 141 December.

Túry, G. - Vida K.(2012): Monitoring jelentés 2012. Politikai és gazdasági elemzés az EU 10 teljesítményéröl. (Monitoring report 2012. Political and economic analysis of the EU 10's performance). IWE, RCERS, HAS.

Yakovlev, A. (2006): The Evolution of Business - State Interaction in Russia: From State Capture to Business Capture? Europe-Asia Studies, Europe-Asia studies. Vol.58, No.7, November:1033-1056. 